\title{
Ecosystem services potential for climate change resilience in peri-urban areas in Sub-Saharan Africa
}

\author{
Lazaro Eliyah Mngumi ${ }^{1,2}$ (D)
}

Received: 23 August 2018 / Revised: 4 March 2019 / Accepted: 27 January 2020 / Published online: 17 February 2020

(c) The Author(s) 2020

\begin{abstract}
Ecosystem services provide considerable development opportunities, including incorporating land use planning and enhancing climate change resilience in peri-urban communities. However, the application of this concept in planning and enhancing climate change resilience is negligible in Sub-Saharan Africa (SSA). This article reviews state-of-the-art research on the potential contribution of peri-urban ecosystem services to climate change resilience in SSA and identifies research gaps for further work. This study was conducted through systematic review of articles from the Web of Science. The literature shows limited knowledge on peri-urban ecosystem services research globally and SSA in particular. The gaps in this knowledge stem from inadequate conceptualization and lack of understanding about how such knowledge can be translated into policy, planning and management and, hence, realizing development goals. In nutshell, the potential for climate change resilience of well-managed peri-urban ecosystem services includes reducing the physical exposure of peri-urban areas to floods and droughts and minimizing climate change risks through increased socio-economic resilience to hazard impacts and provision of the carbon sequestration function. However, specific peri-urban studies describing ecosystem service types and how they can be synchronized into mainstream urban planning and climate change resilience strategies are lacking in most SSA urban regions/landscapes. Therefore, case studies need to be conducted to contextualize and downscale the concept in periurban areas and to determine how the concept can be synchronized into broad urban planning and strategies for enhancing resilience to climate change in vulnerable urban and peri-urban communities.
\end{abstract}

Keywords Climate change · Urban landscape · Sustainable development · Policy $\cdot$ Planning and management

\section{Introduction}

Urban ecosystems remain an open frontier in ecosystem services research (Gómez-Baggethun and Barton 2013; Hernández-Morcillo et al. 2013). Following the release of the article by Bolund and Hunhammar (1999), literature has increasingly striven to sharpen understanding of urban ecosystem services in ecological (Escobedo et al. 2011; Pataki et al. 2011), economic (Jim and Chen 2009; Sander et al. 2010) and socio-cultural domains (Andersson et al. 2007; Barthel et al. 2010). Ecosystem services in urban and

Lazaro Eliyah Mngumi

lazaromngumi@gmail.com; lazaro.mngumi@slu.se

1 Institute of Human Settlements Studies (IHSS) of Ardhi University, P. O. Box 35176, Dar es Salaam, Tanzania

2 Faculty of Natural Resources and Agricultural Sciences, Swedish University of Agricultural Sciences (SLU), P. O. Box 7012, 75007 Uppsala, Sweden peri-urban areas have been categorized by major initiatives, such as the Millennium Ecosystem Assessment (McGranahan et al. 2005) and the Economics of Ecosystems and Biodiversity (TEEB 2011) and have received increasing attention as part of the important debate on green infrastructure (DGEnvironment 2012). However, urban ecosystem services are not given sufficient attention compared to other ecosystems such as wetlands and forests (Gómez-Baggethun and Barton 2013; Kiunsi 2013).

The ecosystem services concept/approach and its application in the urban environment have gained impetus amongst researchers during the last decade (Haase 2013; Kremer et al. 2015). However, given the widespread recognition of the complex and interdisciplinary nature of ecosystem services research (Daily et al. 2009), incorporating a wide range of perspectives is a primary condition for comprehensive conceptualization leading to informed and thereby its effective application (Luederitz et al. 2015). Discipline-based approaches have proven a failure for 
integrating ecosystem services into planning practice, as this integration requires a broad understanding of knowledge, i.e., in the ecological, economic, political and social domains (Carpenter et al. 2009; Haase 2013). Accordingly, urban ecosystem services research ought to encompass not only ecological modelling and economic valuation but also issues such as governance, planning and stakeholder engagement (Luederitz et al. 2015; Kiunsi 2013).

The role of ecosystem services in climate change resilience in urban areas has been increasingly recognized given the growing awareness of the provisioning, regulation, support and cultural benefits of ecosystem services (c). However, this growing research field has received little attention within scholarly circles and amongst practitioners in urban and peri-urban areas (Ricci 2012; Fisher et al. 2009; Costanza and Kubiszewski 2012). The little attention amongst scholars in ecosystem services research in urban and peri-urban areas partly explains why the concept is perceived as abstract and, hence, why it has limited application in climate change resilience, land use planning and other sustainable development discourses (Niemelä et al. 2010; Luederitz et al. 2015). The relations between urban and peri-urban areas are variously conceptualized. Peri-urban is flanked with an array of meanings similar to rural-urban relations owing to diverse geographical orientation and disciplinary bias amongst others (Thuo 2013). However, 'peri-urban' is one of the increasingly used concepts by both practitioners and professionals inferring to a zone of intersection between urban and rural landscapes (Birkmann et al. 2010). Despite the lack of unified conceptualization, there is an increasing understanding on mutual-existing of both urban and rural features within cities and beyond their jurisdictions (Salem 2015). In other words, the cross-cutting feature of different types of space that are regarded peri-urban is that they are transition zones with some degree of intermingling of urban and rural functions (Wandl and Magoni 2016). Furthermore, the quality and quantity of ecosystem services in peri-urban areas are increasingly said to be deteriorating especially those in Sub-Saharan Africa (SSA) (Roy et al. 2017; Assessment 2005a). Further insights on the urban vs peri-urban discourses are expounded in the results/discussion section (s).

This article, therefore, examines the state-of-the-art ecosystem services research in peer-reviewed literature. The aim of the review is to identify the research gaps or systematic bias (i.e., biased focus on particular domains of ecosystem services research in urban and peri-urban areas) in the existing knowledge base, with a focus on (SSA) to trigger further research and application of this growing research field in the region. Key areas that comprise the foci of the review are as described in the materials and methods section below:

\section{Materials and methods}

We reviewed specific sub-theme (s) using the Web of Science (citation) and summarised results in subsequent tables. We used a set of keywords as a guide in searching per every sub-theme. The time interval in every theme was established after the end of the review on the basis of the obtained search results. Below is a detailed description of how the review was carried out whereby specific themes, number of literature reviewed, time intervals in years and the geographical focus is clearly described.

i. Urban development and perspectives on ecosystem services research in SSA; what are the characteristics of urban development in SSA cities, and from which perspectives has ecosystem services research in urban and peri-urban areas been conducted in the region? In this section, we reviewed 22 publications from 2005 to 2018. Our search in this thematic area was limited to the words; ecosystem services research, urban, and SSA. In this thematic area, we reviewed literature from within Africa.

ii. What is peri-urban and what are the associated debates, and what is the nexus between peri-urban and ecosystem services research? In this thematic area, we reviewed a total of 34 peer-reviewed articles from both within and outside Africa from 2000 to 2018 . We confined our search by; peri-urban and ecosystem services as the key search words in the Web of Science.

iii. What are the specific country-urban and peri-urban climate change effects across SSA? Here we reviewed a total of 15 articles and 2 reports from within SSA as summarized in Table 2. We used; climate change effects, urban, SSA as search keywords.

iv. The potential contribution of urban and peri-urban ecosystem services to climate change resilience; what kinds of ecosystem services are considered to contribute substantially to climate change resilience, and what are the different forms of resilience that can be derived from ecosystem services? In this sub-theme, we reviewed 26 peer-reviewed articles from both within and outside Africa. Table 3 presents a summary of ecosystem services (provisioning, regulating and cultural), type of service produced, service generating units and the way each contributes to enhancing resilience to climate change as discussed in peer-reviewed literature.

v. What are the challenges of ecosystem service management in peri-urban areas? What are emerging ecosystem service management approaches and governance issues in urban and peri-urban areas? 


\section{Results and discussion}

\section{Urban development and perspectives of ecosystem services research in SSA}

\section{SSA cities in context}

Cities in SSA have many features in common in terms of social, economic and infrastructure conditions (Kiunsi 2013). In addition, most of these cities are experiencing both development and a climate change adaptation deficit (Kiunsi 2013; Roberts et al. 2012), despite recent efforts to improve infrastructure and housing conditions for low-income groups (Kiunsi 2013). The development deficit in infrastructure and services in SSA cities partly results from inadequate human and capital resources to cope with rapid growth (Kiunsi 2013). There are multiple factors behind adaptation deficits, including the lack of grey infrastructure (e.g., stormwater drainage, sewers, roads), the destruction of green infrastructure (e.g., wetlands, forests, grasslands, productive soils) and inadequate capacity resulting from poverty, poor governance and lack of skill (Roberts et al. 2012; Maconachie 2016). However, SSA's emerging urban areas are largely unplanned, which is closely associated with the growth of informal settlements, inadequate housing and basic services, and urban poverty (Yuen and Kumssa 2010; Kombe 2005). The situation is further worsened by unparalleled levels of population growth (Maconachie 2016; Roberts et al. 2012). Nearly $90 \%$ of the world's urban population currently resides in low-and middle-income countries, mainly in Africa and Asia (Lowe et al. 2009; Laros and Jones 2014; Birch 2016); simultaneously, rapid urbanization is already occurring in SSA (Radford and James 2013; Güneralp et al. 2017). In fact, some cities in East Africa have a population doubling time of 10-15 years (UNECA 2014).

However, risks in a rapidly urbanizing world are increasingly associated with the effects of climate change on urban and peri-urban areas given the massive ecosystem degradation resulting from rapid peri-urban sprawl (IPCC 2014). Rapid urbanization subjects people and ecosystems to risk and effectively urbanizes the poverty, climate change and ecosystem challenge (Roberts et al. 2012; Güneralp et al. 2017). Climate change impacts on urban and peri-urban areas threaten longterm economic development and human well-being (IPCC 2014) and further complicate and challenge the global imperatives of sustainable development and the new urban agenda (Jones et al. 2012; Munroe et al. 2012).

\section{Eecosystem services research perspectives versus rural- urban bias in SSA}

As ecosystem services research in urban areas globally has received modest attention within scholarly circles
(Gómez-Baggethun and Barton 2013), the little attention it has received in an African context is not surprising (Costanza and Kubiszewski 2012). While research and policy regarding ecosystem services have been growing recently, the attention to urban and peri-urban areas has been very limited, especially in SSA (Costanza and Kubiszewski 2012; McPhearson et al. 2016). Studies substantiate relatively more research in the north, while there is a greater need in the south (McPhearson et al. 2016; Zasada 2011). Costanza and Kubiszewski (2012) report that there have been only eight authors from Africa who have published at least five papers on ecosystem services. However, since the beginning of the second millennium, ecosystem services have increasingly become a topical issue for research and debate on scientific platforms (Müller and Burkhard 2012) not only at a global scale but also in Africa (Egoh et al. 2012).

Ecosystem services research in SSA, as in other regions, has been undertaken from three research perspectives, i.e., in ecological (Lwasa 2010; Cavan et al. 2014; Lupala et al. 2014; Romeu-Dalmau et al. 2016), economic (Egoh et al. 2008; Kalaba et al. 2013; Reed et al. 2015), and social domains of knowledge (Roberts et al. 2012; Ricci 2012; Dawson and Martin 2015; Toteng et al. 2005). Table 1 shows the distribution of ecosystem services research from the three research perspectives and provides the geographical location where the studies were conducted in SSA countries. Out of 14 reviewed articles, 4 (29\%) are from a social research perspective, 7 (50\%) are from an ecological perspective and $3(21 \%)$ are from an economic perspective. Regarding rural versus urban bias, out of 14 reviewed articles, 8 (57\%) are rural oriented and $6(43 \%)$ are urban oriented. Furthermore, of the 6 urban-oriented ecosystem service studies in SSA, 4 (67\%) are urban based and 2 (33\%) are peri-urban based. These findings depict considerably few studies on ecosystem services research in urban areas relative to similar studies in rural areas, concurs with the work by (Kiunsi 2013).

Despite considerable recognition of development and the climate change adaptation deficit, the literature indicates little research on ecosystem services in SSA compared to the global north. Similarly, although ecosystem services research has been generally growing recently, the attention allotted to urban and peri-urban areas is not substantial and, hence, needs to be given the attention it deserves.

\section{The peri-urban concept and its bearing on ecosystem services research}

The peri-urban concept has been contested by both academia and development practitioners (Thuo 2013; Forsyth 2012). There is, however, a growing understanding amongst researchers on diverse, context-laden definitions (Brook 2001; Iaquinta and Drescher 2000; Allen 1999; 
Table 1 Classification of ecosystem services research by research perspectives against rural vs urban bias in SSA

\begin{tabular}{llllll}
\hline Research perspectives & Rural & Urban & Peri-urban & Country & References \\
\hline Social & & Urban & & South Africa & Roberts et al. (2012) \\
& & & Peri-urban & Tanzania & Ricci (2012) \\
& Rural & & & Rwanda & Dawson and Martin (2015) \\
& & Urban & Botswana & Toteng et al. (2005) \\
Ecological & & Urban & Tanzania & Cavan et al. (2014) \\
& Rural & & & South Africa & Egoh et al. (2008) \\
& & & Peri-urban & Tanzania & Lupala et al. (2014) \\
& Urban & & & Uganda & Lwasa (2010) \\
& Rural & & & Malawi & Romeu-Dalmau et al. (2016) \\
& Rural & & & Mozambique & Romeu-Dalmau et al. (2016) \\
& Rural & & Swaziland & Romeu-Dalmau et al. (2016) \\
Economic & Rural & & Rwanda & Dawson and Martin (2015) \\
& Rural & & Zambia & Kalaba et al. (2013) \\
& Rural & & Botswana & Reed et al. (2015) \\
\hline
\end{tabular}

Salem 2015; Thuo 2013; Mbiba and Huchzermeyer 2002; Forsyth, 2012). Researchers have attempted to explain the reasons for multiple definitions of the term peri-urban, including the lack of a scientific definition (Simon et al. 2004; Forsyth 2012), diversity of disciplinary perspectives (Thuo 2013), and difficulties associated with delimiting the spatial extent of this dynamic region.

However, there is a growing consensus within academia on the co-existing urban and rural features within cities and beyond their limits (Allen 2006; Narain and Nischal 2007; Salem 2015; URT 2007). The two entities, i.e., urban and rural areas, are argued to be interdependent, and the peri-urban area comprises the point of intersection (Olujimi and Gbadamosi 2007; Rakodi and Lloyd-Jones 2002; Birkmann et al. 2010). Various researchers argue that rural, peri-urban and urban environments operate as a system rather than independently and that rural and urban development are, in principle, linked activities (Iaquinta and Drescher 2000; Wandl and Magoni 2016; Allen 2006; Narain and Nischal 2007; Salem 2015). Iaquinta and Drescher (2000) report that activities or interventions in one arena have consequences, often negative, in another. Wandl and Magoni (2016) and Simon (2008) are of the opinion that the intertwined relationship between urban and rural development suggests creative policies that can change liabilities into resources and bridge the rural-urban divide. Wandl and Magoni further urgued that, peri-urban areas stand to be a potential working laboratory for development planning and management that transcends the jurisdiction of the city in the course of bridging the gap created by the rural-urban divide.

Why, then, should ecosystem services research focus on peri-urban areas? There are multifaceted reasons as to why ecosystem services research should focus on peri-urban areas. However, this review deliberately focuses on three explanations: multiple forces, multifunctionality nature and severe ecosystem degradation.

Regarding the multiple forces at play in this zone, i.e., peri-urban areas, Simon (2008) argued that focusing on periurban areas is imperative because the urban-rural interface is also the area with the most potential for positive management change due to the many forces that converge in this transitional space. Simon (2008) has merely highlighted the presence of forces in peri-urban areas, but one may be curious to know the exact forces at play in peri-urban areas. Masuda and Garvin (2008), Dupont (2004) and Brook and Dávila (2000) followed the same argument; i.e., social, economic, political and cultural forces in peri-urban areas are considered the main forces influencing peri-urban planning and development. Wandl and Magoni (2016), in contrast, provided a more explicit description of the forces at play in peri-urban areas in the global north, such as urban migration, agricultural intensification and changing preferences for the location of urban-related functions, such as distribution centres, waste and wastewater treatment infrastructure and other related functions. Masuda and Garvin (2008) and Maconachie (2016), in analysing the same forces in the context of the global south, mentioned a high demand for land for housing, inadequacies in the regulatory framework and infrastructure, poor planning decisions and land speculation.

The multifunctionality nature, widely referred to as multiple land uses in the literature (McFarland 2015; Kombe 2005), is the overarching characteristic feature of a periurban area in both developed and developing countries (Zasada 2011). The functional interdependence between urban and peri-urban areas partly explains the increasing recognition that cities need to look beyond their jurisdictional boundaries (Lovell and Johnston 2009). These areas are characterized by serious land-use competition whereby multiple actors with common or opposing interests frequently 
come into conflict (McFarland 2015). Agricultural activities can hardly thrive against residential development, but periurban areas often attract those with different value perceptions (e.g., those who value amenities and environmental assets above strict free-market economic criteria) (Knowd et al. 2006; Gosnell et al. 2011).

Despite the vital services ecosystems provide in supporting life, they are globally considered to be under the threat of severe degradation (Assessment 2005a). There is, however, a growing consensus in the literature that the quantity and quality of ecosystems and the associated services are deteriorating in urban and peri-urban areas and particularly those in SSA (Roy et al. 2017, Assessment 2005a). Rapid urbanization under poverty is one of the increasingly popular explanations for ecosystem degradation in urban and peri-urban areas in SSA countries (Kestemont et al. 2011; Niemelä et al. 2010). Ongoing urbanization has resulted in the expansion of the built environment on ecologically sensitive land, especially in peri-urban areas (Marshall et al. 2009; Agrawal et al. 2003; Kombe 2005; Radford and James 2013). Notwithstanding the uneven exponential growth of cities, settlements spread to peri-urban areas (Maconachie 2016). This movement has led to serious negative effects on ecosystems and associated services, including diminished open spaces; increased pressure on natural resources such as water and urban forests; a lack of hygiene and sanitation infrastructure; air pollution; and inadequate provision of basic infrastructure for the collection of household solid waste (Marshall et al. 2009; Agrawal et al. 2003; Dahiya 2003; Kombe 2005; Narain 2009).

Despite the lack of a unified definition for peri-urban areas, it is increasingly considered that these areas form zones of intersection between urban and rural areas and that urban and rural features tend to coexist. They are also regarded as zones of multifunctionality, i.e., multiple land uses with functional interdependence on both urban and rural areas, which suggests that cities should look beyond their boundaries. In contrast, peri-urban areas are considered crucial zones for planning and development changes that transcend municipal/administrative jurisdictions. Furthermore, the literature indicates severe ecosystem degradation in peri-urban areas, especially in SSA, which further suggests the need for more research on how to better plan these areas for the welfare of residents in urban, peri-urban and rural areas at large.

\section{Climate change impacts on urban and peri-urban areas in SSA}

This section describes and discusses climate change impacts on urban and peri-urban areas in countries across SSA.

Climate change notably threatens rapidly growing urban and peri-urban areas in the global south (UN-Habitat 2010;
Yuen and Kumssa 2010). The impacts of climate change on urban and peri-urban areas in SSA include rising temperatures, floods, extreme weather events, and impacts on food and water supplies (Campbell et al. 2008). Country-specific studies in SSA provide detailed accounts of climate change impacts experienced in urban and peri-urban areas. For instance, studies indicate, in Tanzania, rising temperatures in coastal cities, flooding (Secretariat 2011; Douglas et al. 2008), decrease in rainy days, rising sea level and drought incidences (Kiunsi 2013); in Uganda, flooding incidences (Hepworth and Goulden 2008) and increased rainfall (Lwasa 2010); in Zambia, flooding (Nchito 2007); in Mozambique, flooding (Kondo et al. 2002; Douglas et al. 2008); and in Ethiopia, flooding (Douglas et al. 2008). Flooding, the most frequent and evident climate change impact, exerts considerable impact on urban and peri-urban areas in many countries in this region; for example, heavy rains in East Africa in 2002 caused floods and mudslides, which displaced tens of thousands of people in Rwanda, Kenya, Burundi, Tanzania and Uganda, and very heavy flooding occurred in Port Harcourt and Addis Ababa in 2006 (Douglas et al. 2008).

As people crowd into African cities, human impacts on urban and peri-urban land surfaces and drainage intensify. Even moderate storms now produce quite high flows in rivers because of surface runoff from hard surfaces and drains. Water flowing through a series of culverts and concrete channels cannot adjust to changes in the frequency of heavy rain, as natural streams do. These systems are often obstructed by silt and urban debris, particularly when houses are constructed close to the channels. Such situations frequently occur when low- income residents build on lowlying floodplains, on wetlands or above the tidal level on the coast (McGranahan et al. 2007). The effects of climate change are superimposed on these human-induced local land surface modifications (Douglas et al. 2008).

Accordingly, building resilience to climate change impacts in urban and peri-urban areas is necessary, given the increased human activity due to rapid peri-urbanization coupled with increased climate change impacts. However, various researchers argue that urban and peri-urban areas are increasingly regarded as important sites for global response to climate change (Habitat 2011; Hoornweg et al. 2010; Dodman 2009). Notably, the literature broadly suggests that peri-urban ecosystem-based solutions are a vital part of helping vulnerable urban communities adapt to climate change (Munroe et al. 2012). The quest for effective periurban ecosystem services management as an entry point in enhancing community resilience to climate change is a topical issue, as it emerges as a response to the wider global call for considering urban areas as a focus for climate change response (Habitat 2011; Hoornweg et al. 2010).

As presented in Table 2, climate change is clearly no longer a theoretical abstract but rather a tangible reality in 
SSA. However, flooding incidences are more documented throughout countries in SSA than other climate change incidences, such as drought, temperature rise, extreme weather events, sea-level rise, decrease in rainy days, increased rainfall and impacts on food and water supplies. Enhancing resilience to climate change in vulnerable communities is apparent in urban and peri-urban areas in the region. Interestingly, ecosystem-based approaches for enhancing resilience to climate change impacts have been increasingly suggested as viable solutions for helping vulnerable urban and peri-urban communities adapt to climate change.

\section{Pathways to climate change-resilient ecosystem services in peri-urban areas}

Having been exposed to the nexus between the peri-urban concept and ecosystem services research and the climate change impacts in urban and peri-urban areas in SSA, this section discusses the potential contributions of ecosystem services in enhancing community resilience to climate change effects in peri-urban areas.

Climate and ecosystems are highly interactive, at the micro scale in particular, through water and energy cycling (Munang et al. 2010). Munang et al. further urged that climate change at the regional to global scale can be modified by local-scale processes, with serious impacts on biodiversity and ecosystem functioning. Studies affirm that periurban ecosystems are essential for regulating and maintaining ecological processes and life-support services for urban and peri-urban communities (Costanza et al. 1997; Douglas 2006; Barbier 2006). Notwithstanding the diverse urban and peri-urban ecosystem services ranging from provisioning, regulating, habitat, and cultural and amenity values (Daily 1997; Costanza et al. 1997; De Groot et al. 2002; Samper et al. 2005; Kumar 2010), this review is limited to ecosystem services that have the potential to contribute to enhancing community resilience to climate change impacts as described hereafter.

The literature presents the potential of ecosystem services in terms of building community resilience to urban and peri-urban climate change effects. Reducing the magnitude of climate change-related disasters is amongst the potential of ecosystem services for the development of climate change resilience (Barbier 2006) and is said to have twofold effects. First, water bodies or wetlands can reduce physical exposure by serving as natural protective barriers or forms of a buffer zone, thereby mitigating hazardous impacts of climate change that would otherwise be disastrous (Sudmeier-Rieux et al. 2007; Barbier 2006). As Abramovitz et al. (2002) stated, a well-managed ecosystem can provide natural protection against common natural hazards, including floods and storm surges, fires and droughts. However, there is growing evidence throughout ecosystem literature that some vegetation types are better fitted than others to serve as buffers for natural and climate induced-disasters (Mazda et al. 1997; Massel et al. 1999; Chong 2005). Mazda and colleagues further urgued that, for instance, mangrove wetlands situated along sheltered shores in tropical areas are considered more valuable in minimizing damage to property and loss of human life by acting as a barrier against extreme climate events. Second, a well-managed peri-urban ecosystem reduces disaster risks through increased socio-economic resilience to hazard impacts. Socio-economic resilience is created through the provision of essential services, such as food, clothing, medicine, construction material and other livelihood options for strengthening human security and resilience to climate change effects (Abramovitz et al. 2002). Studies have reported the vital role provisioning services fulfil in enhancing resilience in nature-dependent communities and more so in developing countries including those in SSA (Enfors and Gordon 2008; Takasaki et al. 2004; Innes and Hickey 2006).
Table 2 Climate change impacts in urban and peri-urban areas in SSA

\begin{tabular}{lcll}
\hline Climate change incident & Year & Country & References \\
\hline Temperature rise & 2008 & & Campbell et al. (2008) \\
& 2013 & Tanzania & Secretariat (2011) \\
Decrease in rainfall & 2013 & Tanzania & Kiunsi (2013) \\
Increase in rainfall & 2010 & Uganda & Lwasa (2010) \\
Sea level rise & 2013 & Tanzania & Kiunsi (2013) \\
Floods & 2008 & & Campbell et al. (2008) \\
& 2007 & Uganda & Hepworth and Goulden (2008) \\
& 2002 & Rwanda, Kenya, Burundi, & Douglas et al. (2008) \\
& & Tanzania and Uganda & \\
& 2006 & Ethiopia & Douglas et al. (2008) \\
& 2000 & Mozambique & Douglas et al. (2008), Kondo et al. (2002) \\
& 2005 & Zambia & Nchito (2007) \\
Drought & 2013 & Tanzania & Kiunsi (2013) \\
\hline
\end{tabular}


The literature further describes carbon storage and sequestration as amongst the potential ecosystem services for climate change mitigation. However, there is no consensus amongst researchers about the exact contribution that cities make to greenhouse gas (GHG) emissions (Dodman 2009) or about who and what is most vulnerable to the effects of climate change (De Sherbinin et al. 2007). Various studies affirm that carbon stocks, such as ecosystem services in forested and non-forested urban and peri-urban areas, could substantially add to current estimates of local, regional and national carbon balances (Jenkins 1999 cited in (Ugle et al. 2010, Bolund and Hunhammar 1999).

According to Table 3, there is a growing understanding of the considerable climate change resilience opportunities emanating from ecosystem services not only in rural areas but also in urban and peri-urban areas. Three categories of ecosystem services, i.e., provisioning, regulating and cultural services, have been argued as having the potential for enhancing climate change resilience. However, as noted in Sect. 2 above, there is limited research being undertaken in SSA that considers the concept in local urban and periurban settings to reveal typical ecosystem services and their interlinkages to climate change resilience.

\section{Ecosystem services and governance of peri-urban areas}

Following the publication of the Millennium Ecosystem Assessment (MA), ecosystem services have been considered to a greater extent in environmental policies owing to the growing recognition of their vital contributions to human well-being and to the world economy (Egoh et al. 2012). At the global scale, the Convention on Biological Diversity (CBD) has established new targets for 2020, including biodiversity management and delivery of ecosystem services. Target 14 specifically references safeguarding ecosystem services for improving livelihoods and well-being and for addressing the needs of women, indigenous and local communities, the poor and the vulnerable. This concept has successfully drawn attention to the importance of ecosystems in addressing poverty and achieving the Millennium Development Goals (Chong 2014; Egoh et al. 2012).

Although not yet widely used in planning, the ecosystem services approach/concept offers an opportunity for land use planning to develop ecologically sustainable urban regions (inclusive of peri-urban areas) (Niemelä et al. 2010). The approach/concept provides great opportunities complimentary to land use planning and sustainable development (Niemelä et al. 2010). A comprehensive and integrative ecosystem services approach opens the door for considering sustainable development goals in urban planning (Niemelä et al. 2010; Wandl and Magoni 2016; Luederitz et al. 2015). Interestingly, the concept/ approach is considered to have transitioned from a conceptual model for understanding human-environmental interaction to an explicit management tool (Bateman et al. 2013; Daily et al. 2009). It is, however, increasingly used to describe the linkage between ecosystems and human

Table 3 Urban and peri-urban ecosystem services that contributes to enhance climate change resilience

\begin{tabular}{|c|c|c|c|c|}
\hline Category & Ecosystem service & Service generating unit & Region & References \\
\hline \multirow[t]{3}{*}{ Provisioning services } & Timber products & Different tree species & $\begin{array}{l}\text { Europe } \\
\text { SSA } \\
\text { Asia }\end{array}$ & $\begin{array}{l}\text { Matero et al. (2003), Enfors and } \\
\text { Gordon (2008) and Takasaki } \\
\text { et al. (2004) }\end{array}$ \\
\hline & Game, berries, mushrooms & $\begin{array}{l}\text { Different species in land, fresh- } \\
\text { water and sea ecosystems }\end{array}$ & $\begin{array}{l}\text { Europe } \\
\text { SSA }\end{array}$ & $\begin{array}{l}\text { Matero et al. (2003) } \\
\text { Enfors and Gordon (2008) }\end{array}$ \\
\hline & Fresh water, soil & $\begin{array}{l}\text { Groundwater infiltration, suspen- } \\
\text { sion and storage }\end{array}$ & America & Brauman et al. (2007) \\
\hline \multirow[t]{5}{*}{ Regulating services } & Micro-climate regulation & Green cover (vegetation) & Europe & Gill et al. (2007) \\
\hline & Carbon sequestration & Vegetation & $\begin{array}{l}\text { Asia } \\
\text { America } \\
\text { Europe }\end{array}$ & $\begin{array}{l}\text { Ugle et al. (2010) } \\
\text { Balvanera et al. (2005) }\end{array}$ \\
\hline & Protection of coastal areas & Vegetation cover & $\begin{array}{l}\text { Asia } \\
\text { SSA }\end{array}$ & $\begin{array}{l}\text { Das and Vincent (2009) } \\
\text { Mustelin et al. (2010) }\end{array}$ \\
\hline & Rain water absorption & $\begin{array}{l}\text { Vegetation cover, sealed surface, } \\
\text { soil }\end{array}$ & Europe & Bolund and Hunhammar (1999) \\
\hline & Buffer to floods & Wetlands, vegetation & $\begin{array}{l}\text { Asia-Pakistan } \\
\text { Asia-Thailand }\end{array}$ & $\begin{array}{l}\text { Sudmeier-Rieux et al. (2007) } \\
\text { Barbier (2006) }\end{array}$ \\
\hline \multirow[t]{2}{*}{ Cultural services } & Recreation of urban dwellers & $\begin{array}{l}\text { Biodiversity, especially in parks, } \\
\text { forests and water ecosystems }\end{array}$ & Europe- & Bolund and Hunhammar (1999) \\
\hline & $\begin{array}{l}\text { Science education, research and } \\
\text { teaching }\end{array}$ & Biodiversity & Europe & $\begin{array}{l}\text { Matero et al. (2003) } \\
\text { Bolund and Hunhammar (1999) }\end{array}$ \\
\hline
\end{tabular}


well-being in urban regions (Elmqvist 2011; Söderman et al. 2012; Tobias 2013), placing it at the heart of integrated sustainable urban development (Cilliers et al. 2013; Luederitz et al. 2015). The ecosystem services approach/ concept thus creates a framework for developing sustainability science, including broad views from economists and social scientists (apart from ecologists), to acknowledge the multi-faceted approach therein (Le Maitre et al. 2007; Daily et al. 2009). Under ecosystem services, approach/ concept land use planning in peri-urban areas should be participatory and include stakeholders from both urban and rural areas and land use actors in discussing common interests, such as what a should peri-urban area provide to urban society (Vejre et al. 2007; Overbeek 2009; Wandl and Magoni 2016). For sustainable planning and development of peri-urban areas, various researchers argue that an integrated planning approach is required for addressing environmental stewardship, providing ecosystem services and creating green infrastructure, in addition to supporting local economic development and maintaining human well-being (Wandl and Magoni 2016; Luederitz et al. 2015). Very unfortunate, the ecosystem services concept/ approach is still largely perceived as abstract and complex both in academia and amongst practitioners for practical planning (Niemelä et al. 2010; Luederitz et al. 2015).

After considering the usefulness of the ecosystem services concept/approach in land use planning and sustainable development, it is imperative to now discuss peri-urban governance in light of the ecosystem services approach/concept. The growth of peri-urban areas is increasingly recognized as a dominant planning and urban design challenge for the twenty-first century (Thorn et al. 2015). These areas (i.e., peri-urban areas) are often depicted as fragmented administrative and decision-making units, with lines of separation, competition and conflict between urban and rural areas (Zasada 2011; McFarland 2015). Existing interrelationships are side-lined, and their inherent potentialities, for instance, in land use planning, urban agriculture, and ecosystem management, remain underdeveloped (Zasada 2011). There is however an increasing understanding in both academia and amongst practitioners of the unique, complex and multifaceted features of the peri-urban area calling for special attention (Thorn et al. 2015). Urguing in the same direction (Wandl and Magoni 2016), peri-urban areas poses unique governance complexity as they extend over multiple government jurisdictions and thereby affected by fragmented plans and management schemes. This further puts more weight for the need of having special cross-terittorial governance in this zone (peri-urban). In Europe, for instance a distinctive policy framework addressing the issues in peri-urban areas and their surroundings based on their functional interrelationships has been requested (Zasada 2011; Wandl and Magoni 2016).
The scale issue is of great concern when the ecosystem services approach/concept is considered in an urban context. Which scale is appropriate for the application of ecosystem services approach/concept to deliver the desired effect to an urban community? The literature broadly affirms a long-spanning history of failures in policy, management, and assessment, attributing the root of the failure to not properly considering the scale and cross-scale dynamics in human-environment interactions (Assessment 2005b). For instance, problems associated with vulnerability to extreme events such as floods and droughts and the inability to address human-induced environmental hazards. Furthermore, there is an increasing understanding that environmental, geophysical, and ecological phenomena occur over a continuous range of levels, although particular levels may be more important for particular processes (Cash et al. 2006). Concerning ecosystem services approach/concept-in urban areas, researchers propose approaching it at the scale of urban region(s), rather than at the city scale (Niemelä et al. 2010). Niemela et al. added further that, a city, as an administrative unit interacting with its surroundings, cannot realistically serve as a functional unit for the application of ecosystem services approach/concept. In other words, the urban region(s) elsewhere referred to as an urban landscape (Willemen et al. 2008; Christensen et al. 1996), is the ideal scale for integrating ecosystem services approach/concept in urban planning. Landscapes are considered to play a significant role in the application of ecosystem services approach/concept, as they contain many important functions that provide numerous goods and services to society (Willemen et al. 2008; Christensen et al. 1996). Despite the growing body of literature on ecosystem services approach/ concept, the integration of ecosystem services into urban region(s)/landscape planning remains a challenging discourse in many regions, particularly in the developing world (De Groot et al. 2010; Niemelä et al. 2010). There is a substantial discrepancy between the rhetoric and lived reality, which needs to be bridged through continued bottom-up participatory and collaborative research undertaking on one hand coupled with actual ground practice on the other.

\section{Conclusions}

Ecosystem services in peri-urban areas in SSA have the potential for enhancing resilience to climate change effects on vulnerable urban communities. In addition to having the potential for climate change resilience, ecosystem services provide considerable opportunities in complement to land use planning and in the realization of sustainable development discourses. The literature, however, presents some factors that hinder the realization of the benefits related to ecosystem services in urban and peri-urban areas. These hindrances include but are not limited to the following: 
(1) Abstract perception of the ecosystem services concept among the academia, local community (the urbanites) and practitioners. (2) Limited ecosystem services research on urban and peri-urban areas in the region. (3) Difficulties of managing peri-urban areas given the multifunctional nature and interdependence of urban and rural economies, despite the increasing recognition of the peri-urban area as a crucial zone for urban planning and development change. (4) Severe ecosystem degradation fuelled by rapid urbanization under poverty that constrains the delivery of potential ecosystem services. To address the aforementioned factors hindering the realization of ecosystem service benefits in peri-urban areas in SSA, including enhancing resilience to climate change effects, further study in this growing research field is highly recommended. Such research needs to contextualize the ecosystem services concept/approach in a typical setting to demonstrate its usefulness in enhancing resilience to climate change, reducing poverty and supporting wider sustainable development. Furthermore, the research undertaking ought to be bottom-up and participtory in design so as to narrow-down the conceptual differences amongst stakeholders and actors apart from yielding knowledge co-production and extending ownership of the concept/approach to the local community (the urbanites). This will further ensure sustainability of the approach/concept in the local peri-urban setting and provide an easy gateway for its upscaling.

Acknowledgements Open access funding provided by Swedish University of Agricultural Sciences. This article was written as part of the urban governance project under the partnership between the Institute of Human Settlementents Studies (IHSS) of Ardhi University, Tanzania and the Faculty of Natural Resources and Agricultural Sciences of Swedish University of Agricultural Sciences in Sweden. I also gratefully appreciate the financial support of the Swedish International Development Cooperation Agency (SIDA). I thank a team of my supervisors, Matthew Cashmore, Antoienette Warnbard, Makarius Victor Mdemu and Zeinab Eildeen for their comments, suggestions and support at the time I was developing concepts for my project and writing of this article.

Open Access This article is licensed under a Creative Commons Attribution 4.0 International License, which permits use, sharing, adaptation, distribution and reproduction in any medium or format, as long as you give appropriate credit to the original author(s) and the source, provide a link to the Creative Commons licence, and indicate if changes were made. The images or other third party material in this article are included in the article's Creative Commons licence, unless indicated otherwise in a credit line to the material. If material is not included in the article's Creative Commons licence and your intended use is not permitted by statutory regulation or exceeds the permitted use, you will need to obtain permission directly from the copyright holder. To view a copy of this licence, visit http://creativecommons.org/licenses/by/4.0/.

\section{References}

Abramovitz J, Banuri T, Girot PO, Orlando B, Schneider N, SpangerSiegfried E, Switzer J, Hammill A (2002) Adapting to climate change: natural resource management and vulnerability reduction. World Conservation Union-IUCN, Worldwatch Institute, International Institute for Sustainable Development-IISD, Stockholm Environment Institute, Boston

Agrawal M, Singh B, Rajput M, Marshall F, Bell JNB (2003) Effect of air pollution on peri-urban agriculture: a case study. Environ Pollut 126:323-329

Allen A, Da Silva N, Corubolo E (1999) Environmental problems and opportunities of the peri-urban interface and their impact upon the poor. DPU

Allen AD, Dávila JD, Hofmann P (2006) Governance of water and sanitation services for the peri-urban poor; a framework for understanding and action in metropolitan regions. In: Development Planning Unit, U. (ed.). United Kingdom

Andersson E, Barthel S, Ahrné K (2007) Measuring social-ecological dynamics behind the generation of ecosystem services. Ecol Appl 17:1267-1278

Assessment, M. E (2005) Ecosystem and human well-being: biodiversity synthesis. World Resources Institute, Washington, DC

Assessment, M. E (2005) Ecosystems and human well-being: wetlands and water. World Resources Institute, Washington, DC, p 5

Balvanera P, Kremen C, Martinez-Ramos M (2005) Applying community structure analysis to ecosystem function: examples from pollination and carbon storage. Ecol Appl 15(1):360-375

Barbier EB (2006) Natural barriers to natural disasters: replanting mangroves after the tsunami. Front Ecol Environ 4:124-131

Barthel S, Folke C, Colding J (2010) Social-ecological memory in urban gardens-retaining the capacity for management of ecosystem services. Glob Environ Change 20:255-265

Bateman IJ, Harwood AR, Mace GM, Watson RT, Abson DJ, Andrews B, Binner A, Crowe A, Day BH, Dugdale S (2013) Bringing ecosystem services into economic decision-making: land use in the United Kingdom. Science 341:45-50

Birch EL (2016) A midterm report: will habitat III make a difference to the world's urban development? J Am Plann Assoc 82:398-411

Birkmann J, Garschagen M, Kraas F, Quang N (2010) Adaptive urban governance: new challenges for the second generation of urban adaptation strategies to climate change. Sustain Sci 5:185-206

Bolund P, Hunhammar S (1999) Ecosystem services in urban areas. Ecol Econ 29:293-301

Brauman KA, Daily GC, Duarte TKE, Mooney HA (2007) The nature and value of ecosystem services: an overview highlighting hydrologic services. Annu Rev Environ Resour 32(3):67-98

Brook RM (2001) The peri-urban interface Hubli-Dharwad. India Changing Frontiers, Bangalore

Brook RM, Dávila JD (2000) The peri-urban interface: a tale of two cities. School of Agricultural and Forest Sciences, University of Wales, Bangor

IPCC (2014) Climate change 2014-impacts, adaptation and vulnerability: regional aspects, Cambridge University Press, Cambridge

Campbell A, Kapos V, Chenery A, Kahn S, Rashid M, Scharlemann J, Dickson B (2008) The linkages between biodiversity and climate change mitigation. UNEP World Conservation Monitoring Centre

Carpenter SR, Mooney HA, Agard J, Capistrano D, Defries RS, Díaz S, Dietz T, Duraiappah AK, Oteng-Yeboah A, Pereira HM (2009) Science for managing ecosystem services: beyond the Millennium Ecosystem Assessment. Proc Natl Acad Sci 106:1305-1312

Cash D, Adger WN, Berkes F, Garden P, Lebel L, Olsson P, Pritchard L, Young O (2006) Scale and cross-scale dynamics: governance and information in a multilevel world. Ecol Soc. https://doi. org/10.5751/ES-01759-110208

Cavan G, Lindley S, Jalayer F, Yeshitela K, Pauleit S, Renner F, Gill S, Capuano P, Nebebe A, Woldegerima T (2014) Urban morphological determinants of temperature regulating ecosystem services in two African cities. Ecol Ind 42:43-57 
Chong J (2005) Protective values of mangrove and coral ecosystems: a review of methods and evidence. IUCN, Gland

Chong J (2014) Ecosystem-based approaches to climate change adaptation: progress and challenges. Int Environ Agreem: Politics Law Econ 14:391-405

Christensen NL, Bartuska AM, Brown JH, Carpenter S, D'antonio C, Francis R, Franklin JF, Macmahon JA, Noss RF, Parsons DJ (1996) The report of the Ecological Society of America committee on the scientific basis for ecosystem management. Ecol Appl 6:665-691

Cilliers S, Cilliers J, Lubbe R, Siebert S (2013) Ecosystem services of urban green spaces in African countries-perspectives and challenges. Urban Ecosyst 16:681-702

Costanza R, D'arge R, De Groot R, Faber S, Grasso M, Hannon B, Limburg K, Naeem S, O'neill RV, Paruelo J (1997) The value of the world's ecosystem services and natural capital. Nature 387:253-260

Costanza R, Kubiszewski I (2012) The authorship structure of "ecosystem services" as a transdisciplinary field of scholarship. Ecosyst Serv 1:16-25

Dahiya B (2003) Peri-urban environments and community driven development: Chennai, India. Cities 20:341-352

Daily G (1997) Nature's services: societal dependence on natural ecosystems. Island Press, Washington, DC

Daily GC, Polasky S, Goldstein J, Kareiva PM, Mooney HA, Pejchar L, Ricketts TH, Salzman J, Shallenberger R (2009) Ecosystem services in decision making: time to deliver. Front Ecol Environ 7:21-28

Das S, Vincent JR (2009) Mangroves protected villages and reduced death toll during super cyclones. Proc Nat Acad Sci 100(18):7357-7360

Dawson N, Martin A (2015) Assessing the contribution of ecosystem services to human wellbeing: a disaggregated study in western Rwanda. Ecol Econ 117:62-72

De Groot RS, Wilson MA, Boumans RM (2002) A typology for the classification, description and valuation of ecosystem functions, goods and services. Ecol Econ 41:393-408

De Groot RS, Alkemade R, Braat L, Hein L, Willemen L (2010) Challenges in integrating the concept of ecosystem services and values in landscape planning, management and decision making. Ecol Complex 7:260-272

De Sherbinin A, Schiller A, Pulsipher A (2007) The vulnerability of global cities to climate hazards. Environ Urban 19:39-64

Dodman D (2009) Blaming cities for climate change? An analysis of urban greenhouse gas emissions inventories. Environ Urban 21:185-201

Douglas I (2006) Peri-urban ecosystems and societies transitional zones and contrasting values. In: McGregor D, Simon D Thompson D (eds) Peri-urban interface: approaches to sustainable natural and human resource use. Routledge, Abingdon, pp. 18-29.

Douglas I, Alam K, Maghenda M, Mcdonnell Y, Mclean L, Campbell J (2008) Unjust waters: climate change, flooding and the urban poor in Africa. Environ Urban 20:187-205

Dupont V (2004) Urban development and population distribution in Delhi: implications for categorizing population

Egoh BN, O'farrell PJ, Charef A, Gurney LJ, Koellner T, Abi HN, Egoh M, Willemen L (2012) An African account of ecosystem service provision: use, threats and policy options for sustainable livelihoods. Ecosyst Serv 2:71-81

Egoh B, Reyers B, Rouget M, Richardson DM, Le Maitre DC, Van Jaarsveld AS (2008) Mapping ecosystem services for planning and management. Agric Ecosyst Environ 127:135-140

Elmqvist T (2011) Introduction. Section 4 ecosystem services, and social systems in urban landscapes
Enfors EI, Gordon LJ (2008) Dealing with drought: the challenge of using water system technologies to break dryland poverty traps. Glob Environ Change 18:607-616

Escobedo FJ, Kroeger T, Wagner JE (2011) Urban forests and pollution mitigation: analyzing ecosystem services and disservices. Environ Pollut 159:2078-2087

DGENVIRONMENT (2012) The multifunctionality of green infrastructure. European Commission, Brussels

Fisher B, Turner RK, Morling P (2009) Defining and classifying ecosystem services for decision making. Ecol Econ 68:643-653

Forsyth A (2012) Defining suburbs. J Plan Lit 27:270-281

Gill SE, Handley JF, Ennos AR, Paulet S (2007) Adapting cities for climate change: the role of the green infrastructure. Built Environ 33(1):115-133

Gómez-Baggethun E, Barton DN (2013) Classifying and valuing ecosystem services for urban planning. Ecol Econ 86:235-245

Gosnell H, Kline JD, Chrostek G, Duncan J (2011) Is Oregon's land use planning program conserving forest and farm land? A review of the evidence. Land Use Policy 28:185-192

Güneralp B, Lwasa S, Masundire H, Parnell S, Seto KC (2017) Urbanization in Africa: challenges and opportunities for conservation. Environ Res Lett 13:015002

Haase D (2013) Synthesizing different perspectives on the value of urban ecosystem services. Landsc Urban Plann. https://doi. org/10.1016/j.landurbplan.2012.10.010

Habitat U (2011) Global report on human settlements 2011: cities and climate change. United Nations Human Settlements Program Earthscan, London

Hepworth N, Goulden M (2008) Climate change in Uganda: understanding the implications and appraising the response

Hernández-Morcillo M, Plieninger T, Bieling C (2013) An empirical review of cultural ecosystem service indicators. Ecol Ind 29:434-444

Hoornweg D, Bhada P, Freire M, Trejos C, Sugar L (2010) Cities and climate change: an urgent agenda. The World Bank, Washington, DC

Iaquinta DL, Drescher AW (2000) Defining periurban: understanding rural-urban linkages and their connection to institutional contexts. Tenth World Congress of the International Rural Sociology Association

Innes JL, Hickey G (2006) The importance of climate change when considering the role of forests in the alleviation of poverty. Int For Rev 8:406-416

Jim C, Chen WY (2009) Ecosystem services and valuation of urban forests in China. Cities 26:187-194

Jones HP, Hole DG, Zavaleta ES (2012) Harnessing nature to help people adapt to climate change. Nat Clim Change 2:504-509

Kalaba FK, Quinn CH, Dougill AJ (2013) Contribution of forest provisioning ecosystem services to rural livelihoods in the Miombo woodlands of Zambia. Popul Environ 35:159-182

Kestemont B, Frendo L, Zaccai E (2011) Indicators of the impacts of development on environment: a comparison of Africa and Europe. Ecol Ind 11:848-856

Kiunsi R (2013) The constraints on climate change adaptation in a city with a large development deficit: the case of Dar es Salaam. Environ Urban 25:321-337

Knowd I, Mason D, Docking A (2006) Urban agriculture: the new frontier. Changing City Structures, 23

Kombe WJ (2005) Land use dynamics in peri-urban areas and their implications on the urban growth and form: the case of Dar es Salaam, Tanzania. Habitat Int 29:113-135

Kondo H, Seo N, Yasuda T, Hasizume M, Koido Y, Ninomiya N, Yamamoto Y (2002) Post-flood-infectious diseases in Mozambique. Prehospital Disaster Med 17:126-133 
Kremer P, Andersson E, Mcphearson T, Elmqvist T (2015) Advancing the frontier of urban ecosystem services research. Ecosyst Serv 12:149-151

Kumar P (2010) The economics of ecosystems and biodiversity: ecological and economic foundations. UNEP/Earthprint

Laros M, Jones F (2014) The state of African cities 2014: re-imagining sustainable urban transitions

Le Maitre DC, O'farrell PJ, Reyers B (2007) Ecosystems services in South Africa: a research theme that can engage environmental, economic and social scientists in the development of sustainability science? S Afr J Sci 103:367-376

Lovell ST, Johnston DM (2009) Creating multifunctional landscapes: how can the field of ecology inform the design of the landscape? Front Ecol Environ 7:212-220

Lowe A, Foster J, Winkelmand S (2009) Ask the climate question: adapting to climate change impacts in urban regions. Center for Clean Air Policy, Washington DC

Luederitz C, Brink E, Gralla F, Hermelingmeier V, Meyer M, Niven L, Panzer L, Partelow S, Rau A-L, Sasaki R (2015) A review of urban ecosystem services: six key challenges for future research. Ecosyst Serv 14:98-112

Lupala JM, Mdemu MV, Butungo SP (2014) Effects of peri-urban land use changes on forest ecosystem services: the case of settlements surrounding Pugu and Kazimzumbwi forest reserves in Tanzania. J Geogr Geol 6:231

Lwasa S (2010) Adapting urban areas in Africa to climate change: the case of Kampala. Curr Opin Environ Sustain 2:166-171

Maconachie R (2016) Urban growth and land degradation in developing cities: change and challenges in Kano Nigeria. Routledge, Abingdon

Marshall F, Waldman L, Macgregor H, Mehta L, Randhawa P (2009) On the edge of sustainability: perspectives on peri-urban dynamics. STEPS

Massel S, Furukawa K, Brinkman R (1999) Surface wave propagation in mangrove forests. Fluid Dyn Res 24:219-249

Masuda JR, Garvin T (2008) Whose heartland?: The politics of place in a rural-urban interface. J Rural Stud 24:112-123

Matero J, Saastamoinen O, Kouki J (2003) Metsien tuottamat ecosysteemipalvelut ja niiden arvottaminen (Ecosystem services produced by forests and their valuation). Metsatieteen Aikakauskarja 3(1):355-384 (in Finnish)

Mazda Y, Wolanski E, King B, Sase A, Ohtsuka D, Magi M (1997) Drag force due to vegetation in mangrove swamps. Mangroves Salt Marshes 1:193-199

Mbiba B, Huchzermeyer M (2002) Contentious development: periurban studies in sub-Saharan Africa. Prog Dev Stud 2:113-131

Mcfarland P (2015) The peri-urban land-use planning tangle: an Australian perspective. Int Plann Stud 20:161-179

Mcgranahan G, Marcotullio P, Bai X, Balk D, Braga T, Douglas I, Elmqvist T, Rees W, Satterthwaite D, Songsore J (2005) Urban systems, chapter 27. In: "Current state and trends: findings of the condition and trends working group. Ecosystems and human well-being, volume 1", ed. Millennium Ecosystem Assessment. Island Press, Washington, DC, pp 795-825

Mcgranahan G, Balk D, Anderson B (2007) The rising tide: assessing the risks of climate change and human settlements in low elevation coastal zones. Environ Urban 19:17-37

Mcphearson T, Parnell S, Simon D, Gaffney O, Elmqvist T, Bai X, Roberts D, Revi A (2016) Scientists must have a say in the future of cities. Nat News 538:165

Müller F, Burkhard B (2012) The indicator side of ecosystem services. Ecosyst Serv 1:26-30

Munang R, Rivington M, Takle E, Mackey B, Thiaw I, Liu J (2010) Climate information and capacity needs for ecosystem management under a changing climate. Procedia Environ Sci 1:206-227
Munroe R, Roe D, Doswald N, Spencer T, Möller I, Vira B, Reid H, Kontoleon A, Giuliani A, Castelli I (2012) Review of the evidence base for ecosystem-based approaches for adaptation to climate change. Environ Evid 1:13

Mustelin J, Klein RG, Assaid B, Sitari T, Khamis M, Mzee A, Haji T (2010) Understanding current and future vulnerability in coastal settings: community perceptions and preferences for adaptation in Zaanzibar, Tanzania. Population Environ 31(5):371-398

Narain V (2009) Growing city, shrinking hinterland: land acquisition, transition and conflict in peri-urban Gurgaon, India. Environ Urban 21:501-512

Narain V, Nischal S (2007) The peri-urban interface in Shahpur Khurd and Karnera, India. Environ Urban 19:261-273

Nchito WS (2007) Flood risk in unplanned settlements in Lusaka. Environ Urban 19:539-551

Niemelä J, Saarela S-R, Söderman T, Kopperoinen L, Yli-Pelkonen V, Väre S, Kotze DJ (2010) Using the ecosystem services approach for better planning and conservation of urban green spaces: a Finland case study. Biodivers Conserv 19:3225-3243

Olujimi J, Gbadamosi K (2007) Urbanisation of peri-urban settlements: a case study of Aba-Oyo in Akure, Nigeria. Soc Sci 2:60-69

Overbeek G (2009) Opportunities for rural-urban relationships to enhance the rural landscape. J Environ Plann Policy Manage 11:61-68

Pataki DE, Carreiro MM, Cherrier J, Grulke NE, Jennings V, Pincetl S, Pouyat RV, Whitlow TH, Zipperer WC (2011) Coupling biogeochemical cycles in urban environments: ecosystem services, green solutions, and misconceptions. Front Ecol Environ 9:27-36

Radford KG, James P (2013) Changes in the value of ecosystem services along a rural-urban gradient: a case study of Greater Manchester, UK. Landsc Urban Plann 109:117-127

Rakodi C, Lloyd-Jones T (2002) Urban livelihoods: a people-centred approach to reducing poverty. Routledge, Londao

Reed MS, Stringer LC, Dougill AJ, Perkins JS, Atlhopheng JR, Mulale K, Favretto N (2015) Reorienting land degradation towards sustainable land management: linking sustainable livelihoods with ecosystem services in rangeland systems. J Environ Manage 151:472-485

Ricci L (2012) Peri-urban livelihood and adaptive capacity: urban development in Dar Es Salaam. Sustain Dev 7:46-63

Roberts D, Boon R, Diederichs N, Douwes E, Govender N, Mcinnes A, Mclean C, O'donoghue S, Spires M (2012) Exploring ecosystembased adaptation in Durban, South Africa:"learning-by-doing" at the local government coal face. Environ Urban 24:167-195

Romeu-Dalmau C, Gasparatos A, Von Maltitz G, Graham A, Almagro-Garcia J, Wilebore B, Willis KJ (2016) Impacts of land use change due to biofuel crops on climate regulation services: five case studies in Malawi. Mozambique and Swaziland. Biomass Bioenergy. 114:30-40

TEEB (2012) The economics of ecosystems and biodiversity: ecological and economic foundations. Routledge, London

Roy MK, Shemdoe R, Hulme D, Mwageni N, Gough A (2017) Climate change and declining levels of green structures: Life in informal settlements of Dar es Salaam, Tanzania. Landsc Urban Plann 180:282-293

Salem M (2015) Peri-urban dynamics and land-use planning for the Greater Cairo Region in Egypt. Sustain Dev (2 Volume Set) 168:1109

Samper C, Scholes R, Watson RT, Zakri A, Shidong Z, Ash NJ, Bennett E, Kumar P, Lee MJ, Raudsepp-Hearne C (2005) Millennium Ecosystem Assessment: ecosystems and human well-being: Synthesis. Island Press, Washington, DC, p ix

Sander H, Polasky S, Haight RG (2010) The value of urban tree cover: a hedonic property price model in Ramsey and Dakota Counties, Minnesota, USA. Ecol Econ 69:1646-1656 
P-AS Secretariat (2011) International START Secretariat. Tanzania Meteorological Agency and Ardhi University, Tanzania

Simon D (2008) Urban environments: issues on the peri-urban fringe. Annu Rev Environ Resour 33:167-185

Simon D, Mcgregor D, Nsiah-Gyabaah K (2004) The changing urbanrural interface of African cities: definitional issues and an application to Kumasi, Ghana. Environ Urban 16:235-248

Söderman T, Kopperoinen L, Shemeikka P, Yli-Pelkonen V (2012) Ecosystem services criteria for sustainable development in urban regions. J Environ Assess Policy Manage 14:1250008

Sudmeier-Rieux K, Qureshi R, Peduzzi P, Nessi J, Breguet A, Dubois J, Jaboyedoff M, Jaubert R, Rietbergen S, Klaus R (2007) Disaster risk, livelihoods and natural barriers, strengthening decisionmaking tools for disaster risk reduction, a case study from Northern Pakistan. The world conservation union (IUCN) Pakistan programme, Final report, Karachi

Takasaki Y, Barham BL, Coomes OT (2004) Risk coping strategies in tropical forests: floods, illnesses, and resource extraction. Environ Dev Econ 9:203-224

TEEB (2011) TEEB manual for cities: ecosystem services in urban management. The Economics of Ecosystems and Biodiversity, Suiza, Suiza

Thorn J, Thornton TF, Helfgott A (2015) Autonomous adaptation to global environmental change in peri-urban settlements: evidence of a growing culture of innovation and revitalisation in Mathare Valley Slums, Nairobi. Glob Environ Change 31:121-131

Thuo ADM (2013) Unsettled settled spaces: searching for a theoretical 'home' for rural-urban fringes. International Journal of Scientific and Research Publications, 3.
Tobias S (2013) Preserving ecosystem services in urban regions: challenges for planning and best practice examples from Switzerland. Integr Environ Assess Manage 9:243-251

Toteng E, Mbaiwa J, Moswete N (2005) Community attitudes and perceptions towards urban ecological issues in Maun and Gaborone, Botswana. Botswana Notes and Records 37:108-124

Ugle P, Rao S, Ramachandra T (2010) Carbon sequestration potential of urban trees. Wetlands

UNECA (2014) Annual report, United Nations, Economic Commission for Africa. United Nations, Addis Ababa

UN-Habitat 2010The State of African Cities 2010; Population of African Cities to Triple. UN Habitat

URT (2007) National Adaptation Programme of Action. Vice President's Office, Division of Environment, Dar es Salaam

Vejre H, Abildtrup J, Andersen E, Andersen PS, Brandt J, Busck A, Dalgaard T, Hasler B, Huusom H, Kristensen LS (2007) Multifunctional agriculture and multifunctional landscapes-land use as an interface. Multifunctional land use. Springer, New York

Wandl A, Magoni M (2016) Sustainable planning of peri-urban areas: introduction to the special issue. Plann Pract Res 32:1-3

Willemen L, Verburg PH, Hein L, Van Mensvoort ME (2008) Spatial characterization of landscape functions. Landsc Urban Plann 88:34-43

Yuen B, Kumssa A (2010) Climate change and sustainable urban development in Africa and Asia. Springer, New York

Zasada I (2011) Multifunctional peri-urban agriculture-a review of societal demands and the provision of goods and services by farming. Land Use Policy 28:639-648 